\title{
Marine Fisheries Management and Utilization of Fishing Ground in Malaysia
}

\author{
Yasuki OGAWA ${ }^{1 *}$ \\ Fisheries Division, Japan International Research Center for Agricultural Sciences (JIRCAS) \\ (Tsukuba, Ibaraki 305-8686, Japan)
}

\begin{abstract}
Under the marine capture fisheries management in Malaysia, the marine fishing ground is zoned into four areas simply according to the distance from the seashore: zone A from the seashore (0) to 5 nautical miles (nm), zone B from 5 to $12 \mathrm{~nm}$, zone C from 12 to $30 \mathrm{~nm}$, and zone C2 of more than $30 \mathrm{~nm}$. In addition, all fishing gear is classified as either commercial fishing gear of high catch capability or traditional fishing gear of comparatively low catch capability. Fishing gear classified as commercial gear is permitted to be operated only at sea. Further restrictions are imposed on the operation of trawl net and fish purse seine gear which are classified as commercial fishing gear. Namely, their operation is allowed exclusively at sea more than 5 nautical miles $(\mathrm{nm})$ offshore, i.e. in zone $\mathrm{B}$, zone $\mathrm{C}$ and zone C2. Moreover, their operation onboard fishing boats of 40 to 70 GRT (Gross Registered Tonnage) is allowed exclusively from $12 \mathrm{~nm}$ offshore, i.e. in zone $\mathrm{C}$ and zone $\mathrm{C} 2$, while operation from boats of more than 70 GRT is allowed in fishing ground more than $30 \mathrm{~nm}$ offshore, i.e. only in zone $\mathrm{C} 2$. On the other hand, all kinds of fishing gear classified as traditional fishing gear can be operated in any fishing ground. Traditional gear is operated in lakes, rivers, estuaries and from coastal waters to further offshore, i.e. zone A, zone B, zone C and zone C2. It has been proved that in the 1990's almost one fourth of the total marine catch from Peninsular Malaysia was derived from zone A, namely from the shallowest, narrowest and nearest fishing ground to the mainland. Consequently, this management system is perceived to be very appropriate for preventing overfishing of aquatic animal resources in coastal waters including zone A by fishing gear such as trawl net and fish purse seine gear of high catch capability, because coastal waters including zone A are considered to be fishing ground of extremely high productivity.
\end{abstract}

Discipline: Fisheries

Additional key words: zonation of fishing ground, commercial fishing gear, traditional fishing gear

\section{Introduction}

Malaysia consists of East Malaysia and Peninsular Malaysia (Fig. 1). East Malaysia faces the Celebes Sea in the east, the Sulu Sea in the north and the South China Sea in the west. Peninsular Malaysia faces the South China Sea in the east, the Straits of Malacca in the west and the Andaman Sea in the northwest. Both East Malaysia and Peninsular Malaysia face the South China Sea which is an extensive fishing ground, they share in common.

Aquatic animal resources are living resources which must reproduce to provide a sustainable catch. However, once they suffer a large loss, for example excessive human exploitation by overfishing, it is said that they will take an enormously long time to recover from the loss. From this viewpoint, some degree of management is needed to prevent overfishing of aquatic animal resources.

The author had an opportunity of collecting information on marine capture fisheries management and

The information on marine capture fisheries management and utilization of fishing ground in Malaysia was derived through the cordial cooperation of Research Officers in the Fisheries Research Institute, Department of Fisheries Malaysia. The author wishes to express their sincere gratitude for their constant support and goodwill.

Present address:

${ }^{1}$ Seikai National Fisheries Research Institute, Fisheries Research Agency (Nagasaki, Nagasaki 851-2213, Japan)

*Corresponding author: fax +81-95-850-7767; e-mail ogawayas@fra.affrc.go.jp

Received 11 August 2003; accepted 13 February 2004. 


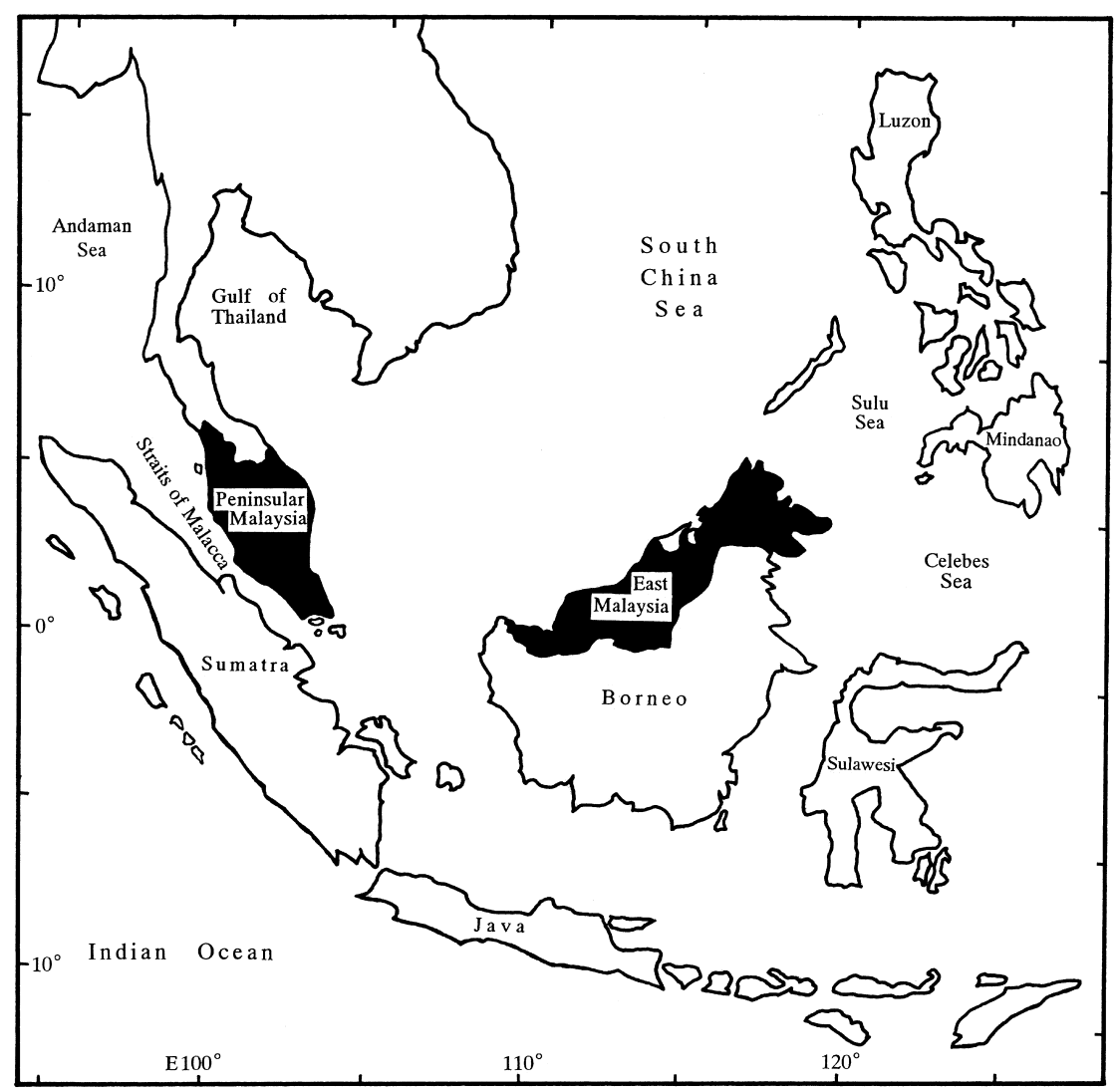

Fig. 1. Map of Malaysia showing adjacent seas

actual utilization conditions of fishing ground in Malaysia. The present paper is a concise report describing them. The marine catches from Peninsular Malaysia under the management system are also described briefly.

\section{Materials and methods}

The information on marine capture fisheries management and utilization of fishing ground in Malaysia was derived from the Research Officers in the Fisheries Research Institute, Department of Fisheries Malaysia. The data on marine catches from Peninsular Malaysia was collected from the Annual Fisheries Statistics (19701999) ${ }^{1}$.

\section{Results}

\section{Marine capture fisheries management}

The marine capture fisheries management in Malaysia has two unique points. One is that the marine fishing ground is zoned into four areas simply according to the distance from seashore, namely zone A from seashore (0) to 5 nautical miles (nm), zone B from 5 to $12 \mathrm{~nm}$, zone $C$ from 12 to $30 \mathrm{~nm}$, and zone $\mathrm{C} 2$ of more than $30 \mathrm{~nm}$ (Fig.
2).

The other unique point is that every kind of fishing gear is classified as either commercial fishing gear or traditional fishing gear, according to the catch capability. Four kinds of fishing gear of high catch capability, such as trawl net, fish purse seine, anchovy purse seine and other seine gear form the group of commercial fishing gear, while another 11 kinds of fishing gear of comparatively low catch capability, such as push net, bag net, gill net, fish trap, longline, etc. form the group of traditional fishing gear.

\section{Fishing ground utilization management}

All kinds of fishing gear classified as commercial fishing gear are permitted to be operated only at sea (Fig. 2 ). In addition, the marine capture fisheries management imposes further restrictions on the operation of only two kinds of commercial fishing gear, i.e. trawl net and fish purse seine gear. Namely, the operation of trawl net and fish purse seine gear is allowed exclusively at sea more than 5 nautical miles (nm) offshore, i.e. in zone $\mathrm{B}$, zone $\mathrm{C}$ and zone $\mathrm{C} 2$. Moreover, their operation onboard fishing boats of 40 to 70 GRT (Gross Registered Tonnage) is allowed exclusively from $12 \mathrm{~nm}$ offshore, i.e. in zone $\mathrm{C}$ 


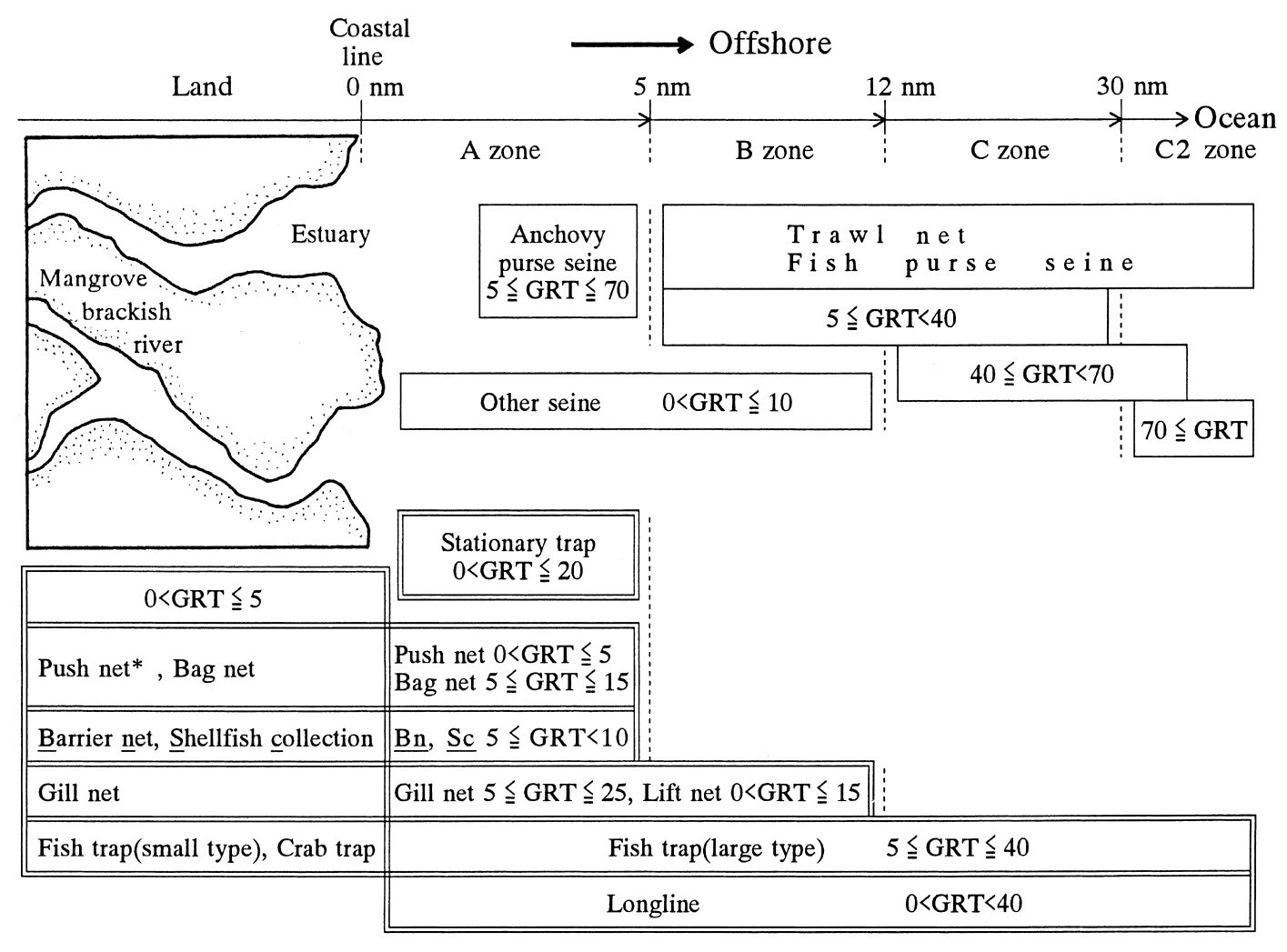

Fig. 2. Schematic view of fishing gear being operated and utilization of fishing ground in Malaysia $\mathrm{nm}$ : nautical mile $(1 \mathrm{~nm}=1,852 \mathrm{~m})$. $\square$ : commercial fishin gear. $\square$ : traditional fishing gear. GRT: Gross Registered Tonnage of the fishing boat.

*: Perak State only.

and zone $\mathrm{C} 2$, while that of more than $70 \mathrm{GRT}$ is allowed further offshore at sea more than $30 \mathrm{~nm}$ offshore, i.e. only in zone $\mathrm{C} 2$.

In spite of that, anchovy purse seine gear and other seine gear also classified as commercial fishing gear have no restrictions imposed on their operation at sea as well there are no restrictions on the operation of all kinds of traditional fishing gear. This is because anchovy purse seine gear is usually operated in coastal waters around islands and coral reefs, which correspond mostly to zone A. Other seine gear is normally judged to be low in catch capability, since they are operated in coastal waters with not only small-scaled nets but also with small-sized fishing boats of less than 10 GRT.

On the other hand, all kinds of traditional fishing gear can be operated in any fishing ground such as lakes, rivers including mangrove brackish waters, estuaries and from coastal waters to offshore seas, i.e. zone A, zone B, zone $\mathrm{C}$ and zone $\mathrm{C} 2$. However, as shown in Fig. 2, it is known that their fishing grounds at sea are apt to be mainly in coastal waters, i.e. in zone A, since their operation is usually conducted by small fishing boats of up to 15 GRT at most.

\section{Marine catches from Peninsular Malaysia under this management system}

Total annual marine catches from Peninsular Malaysia increased almost consistently for 30 years, growing 3.1 times from 293,000 tons in 1970 to 903,000 tons in 1999 (Fig. 3). This increase is perceived to be due to an increase of the catches by commercial fishing gear, in particular due to mainly an increase of the catches by trawl net gear at least from the year 1986 onwards. The average percentage of catches by trawl net gear from the year 1980 to 1985 was no more than $38 \%$, but it grew largely up to $60 \%$ in the 1990 s followed by $17 \%$ for fish 


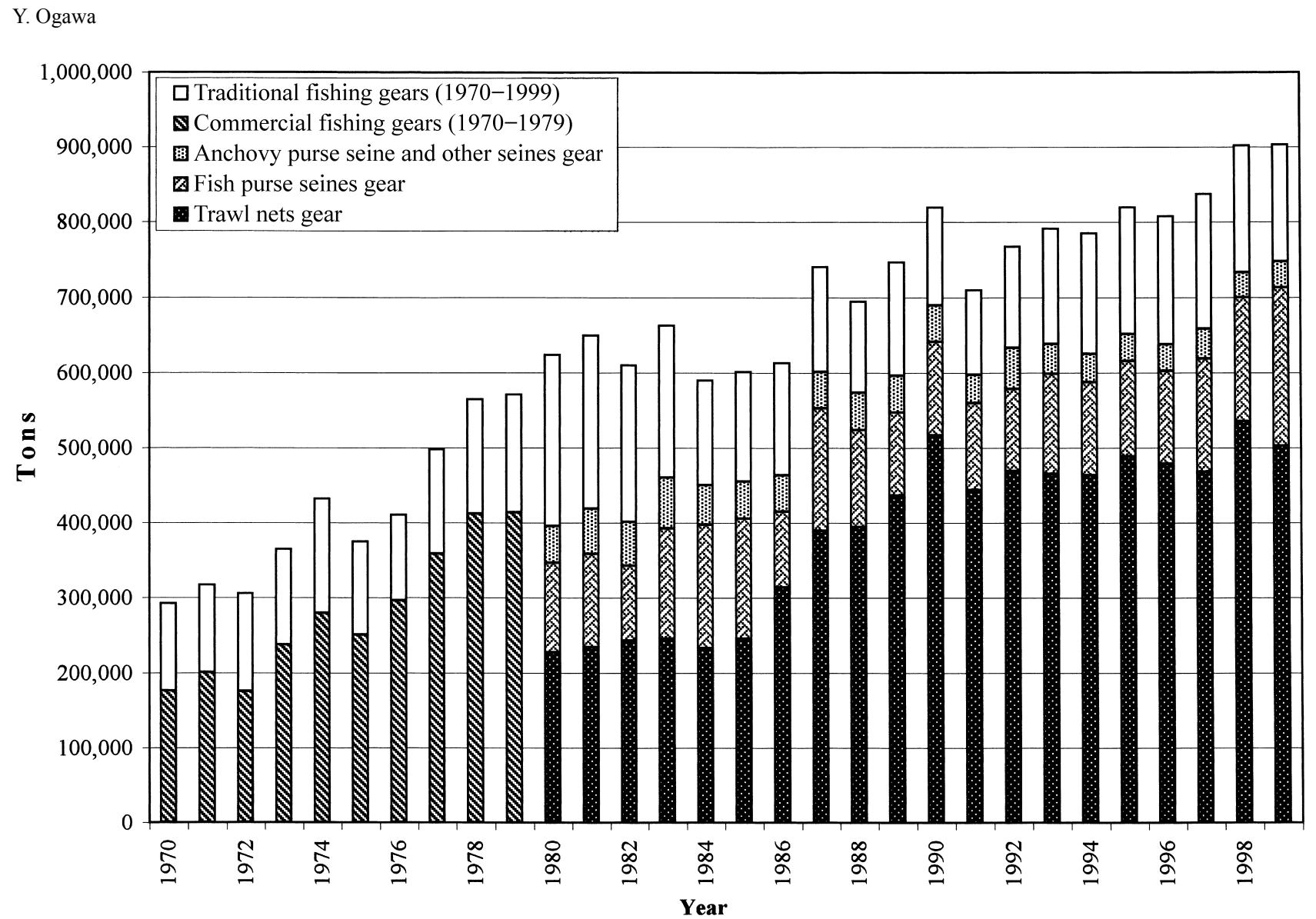

Fig. 3. Total marine catches by fishing gear in Peninsular Malaysia

purse seine gear. Consequently, the average percentage for catches by traditional fishing gear grew gradually less from $33 \%$ in the 1970 s to $27 \%$ in the 1980 s and to $19 \%$ in the 1990s.

However, when it is assumed from Fig. 2 that other commercial seine gear and traditional fishing gear such as gill net, lift net, fish trap (large type) and longline gear are operated exclusively in zone $\mathrm{A}$, the sum of the catches by other commercial seine gear and anchovy purse seine gear and catches by all traditional fishing gear add up to all the catches from zone A (Fig. 3). In this case, in the 1990s the average percentage for all those catches deriving from zone $\mathrm{A}$ is $24 \%$, namely almost one fourth of the total marine catches from Peninsular Malaysia is to be derived from the shallowest, narrowest and nearest fishing ground to the mainland.

\section{Discussion}

According to the marine capture fisheries management in Malaysia, the restrictions imposed on the operation of trawl net and fish purse seine gear are the strictest of all kinds of fishing gear. This is to push the operation of fishing gear of high catch capability offshore as far as possible away from the seashore, in order to conserve aquatic animal resources in coastal waters, in other words to prevent overfishing.

This management system is perceived to be very appropriate for preventing overfishing of aquatic animal resources in coastal waters including zone A by fishing gear of high catch capability such as trawl net and fish purse seine gear. Aquatic animal resources particularly in zone A must be strictly protected from overfishing, because zone $\mathrm{A}$ is considered to be most apt to suffer from it. Zone $\mathrm{A}$ is a fishing ground of extremely high productivity contributing almost one fourth of the total marine catches from Peninsular Malaysia, and is the shallowest, narrowest and nearest fishing ground to the mainland.

\section{Reference}

1. Department of Fisheries Malaysia (1970-1999) Annual fisheries statistics. Department of Fisheries Malaysia, Ministry of Agriculture, Kuala Lumpur. 